Historic, Archive Document

Do not assume content reflects current scientific knowledge, policies, or practices. 
62.09

$$
z^{92 z_{0}}
$$

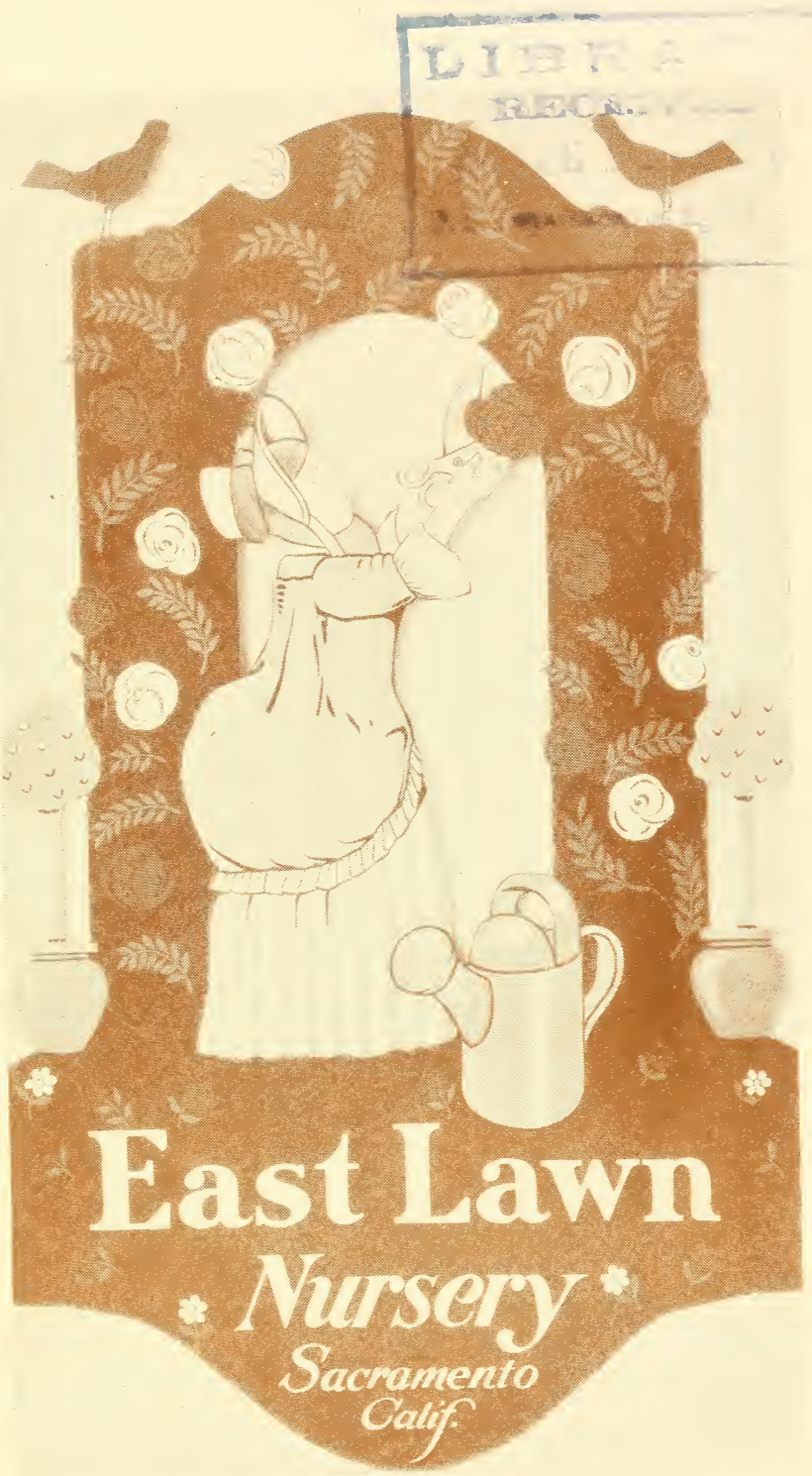




\section{The Fellowship of}

\section{Growing Trees}

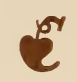

To BE in line with worthy folk you must plant an elm or oak, a beech or maple, fair to see, a single or a double tree. When winter's storms no longer roll, go get a spade and dig a hole, and bring a sapling from the woods and show your neighbors you're the goods. II hat though with years you're bowed and bent and feel your life is nearly spent? The tree you plant will rear its limbs and there the birds will sing their hymns, and in its cool and grateful shade the girls will sip their lemonade; and lovers there on moonlight nights will get Dan Cupid dead to rights; and fervid oaths and tender vows will go a zipping through its boughs. And folks will say, with gentle sigh, "Long years ago an ancient guy, whose whiskers brushed against his knee, inserted in the soil this tree. 'Twas but a little sapling then, and he, the kindest of old men, was well aware that he'd be dead long ere its branches grew and spread, but still he stuck it in the mold and never did his feet grow cold. Oh, he was wise and kind and brave-let's place a nosegay on his grave."

- Malt. Mason.

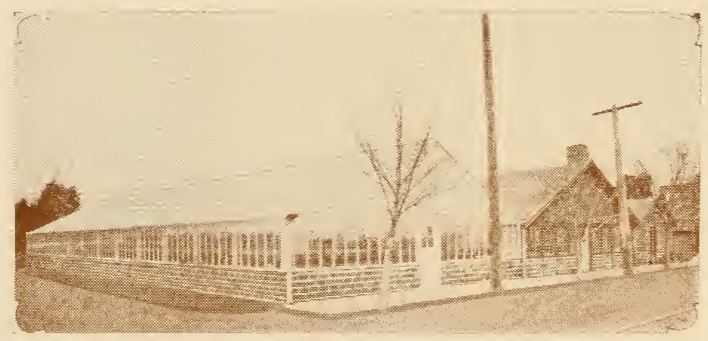

Exterior of Greenhouses

East Lawn Nursery 
Catalog " $E$ "

\section{GeNeral NuRsery}

A N D

BEDDING STOCK

Ornamental Trees

and Shrubbery, Vines, Roses,

Hedge Plants, Etc., Etc.

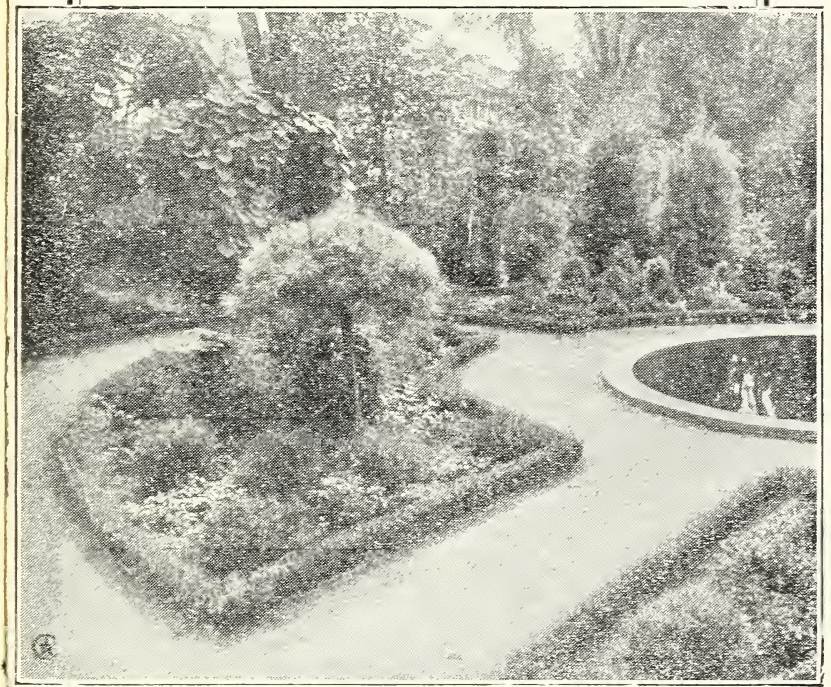

Box-Barberry. See Paǵe Thirteen

Members :

American Rose Society

California Association of Nurserymen

American Association of Nurserymen

East Lawn Nursery

A. GRUIKSHANKS, Superintendent

R. F.D. No. 2 - Phone Gapital 45

SACRAMENTO, CALIFORNIA 46th and Folsom Boulevard 


\section{About Trees Along the Road}

Dr. Frank Crane writes as follow's in the Philadelphia Bulletin

TF I were asked what, of all the beautiful things I saw in the beautiful country of France, was the most beautiful, I should unhesitatingly reply:

"The trees along the road."

I have only to close my eyes to see them now-the long white road stretching a way, and above it the arched trees.

It seems to be a general custom here to line the highway with trees. And it bespeaks at once the taste, the good sense, and the thrift of these people.

Trees are beautiful anywhere-in their native forest, clumped in meadows where the cows shelter in their shade, about the house, in the garden, and in the park-but take it all in all, I think I like them best by the roadside.

There they are public-everybody's trees, as trees ought to be. They shade equally the king in his coach and the vagabond asleep at their feet.

And they are there deliberately. Men must plant them there. And so it shows men appreciate them. They stand as invited guests. They are deservedly honored.

And there is something about a row of trees that is especially appealing. It is the most magnificent of processions. It is the permanent standing army of beauty.

As you look down a long avenue of trees you find it easy to believe that architects got their first idea of a cathedral nave from the spectacle of their meeting branches.

Such a tree-guarded road is splendidly, solidly, spiritually charming.

When I think of the infinite reaches of treeless bare roads I have traversed in America, I wonder why we could not follow the hint of the French.

For these trees are valuable, economically as well as sentimentally. They say one-tenth of France is in trees.

The Government carefully looks after forestry. For wood is a considerable national asset. Some day America is going to wake up to the necessity of conserving its trees.

One of the most distressing pictures of the wardevastated area that remains in my mind is that of miles of road with the trees all cut down, whether by artillery or by the malice of the German army. 


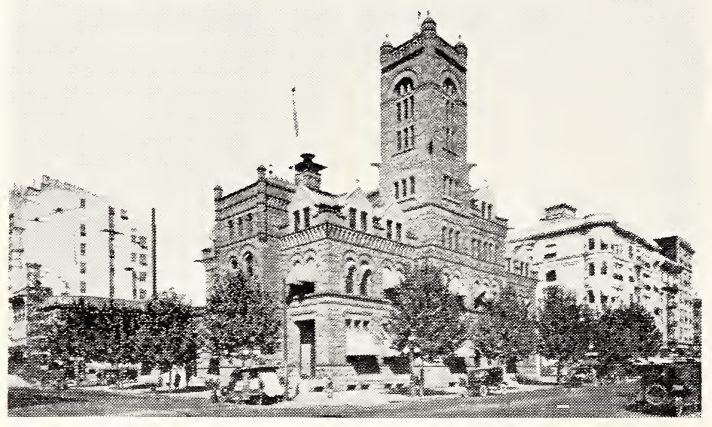

Ornamental Plane Trees Planted Around the Sacramento Post Office

\section{TREES}

EVERGREENS planted singly or in groups as specimens are pleasing in appearance at all seasons of the year and, on account of the variety of coloring and form from which we may choose, there is always some species adaptable to any particular situation where such trees would be appropriate. These trees are also desirable in Evergreen boundary plantings. Many of those listed here will grow into splendid specimens.

LAWSON CYPRESS. Very beautiful evergreen. Native of California. Tall, well-shaped tree. Four varieties. Some with rich green foliage; others intensively silvery. Highly recommended for planting here. $\$ 6.50$ to $\$ 9.50$ each.

NORDMANN'S FIR. The rich, dark, glossy green effect of this compact, slow-growing conical tree is especially attractive. 1 to $1 \frac{1}{2} \mathrm{ft}$. high, $\$ 3.00$ each; 2 to $2 \frac{1}{2} \mathrm{ft}$. high, $\$ 4.00$ each.

CEDRUS DEODARA (Indian Cedar). An especially handsome tree. Branches have a graceful droop; foliage silvery-green. One of the most rapid growing and picturesque of all the Cedars. \$2.00 to $\$ 5.00$ each.

CHESTNU'T, Horse Scarlet, 8 to $10 \mathrm{ft}$., $\$ 1.50$ each.

CHESTNUT (European). Very handsome. 4 to 6 ft., $\$ 1.25$ each. 
Evergreen and Deciduous Trees for Park, Home and Street Planting

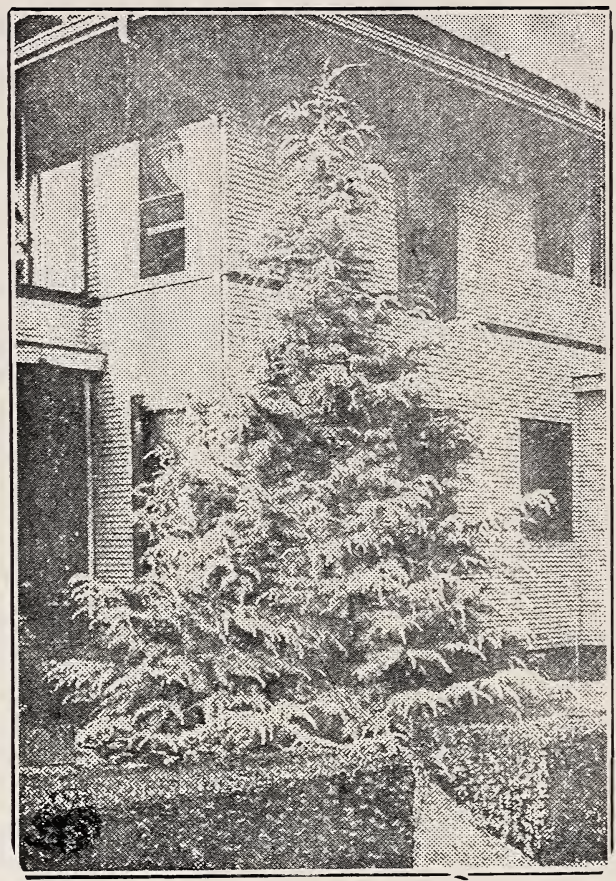

Gedrus Deodara

CRYPTOMERIA ELEGANS (Bush). Low growth; foliage turns to a bronzy crimson in the Fall. Rare. $\$ 1.50$ to $\$ 3.50$ each.

CRYPTOMERIA ELEGANS (Standard). Long stem, with fine rounded heads. $\$ 7.50$ to $\$ 10.00$ each.

CYPRESS (Italian). Tall, tapering tree; branches grow parallel with trunk. $75 \mathrm{c}$ to $\$ 7.50$ each.

CYPRESS (Monterey). Makes fine wind break; close, dense growing. $75 \mathrm{c}$ to $\$ 2.00$ each.

CAMPHOR TREE. Very handsome tree. Leaves glossy green and scented with camphor. Turns crimson in fall. In cans, $\$ 1.50$ to $\$ 2.50$ each.

CASUARINA STRICTA (Australian Beef Wood). Grows well on alkaline soil. Fine, rapid-growing tree. Makes good hedge. Stands trimming well. $\$ 1.00$ to $\$ 2.00$ each. 
Evergreen and Deciduous Trees for Park, Home and Street Planting

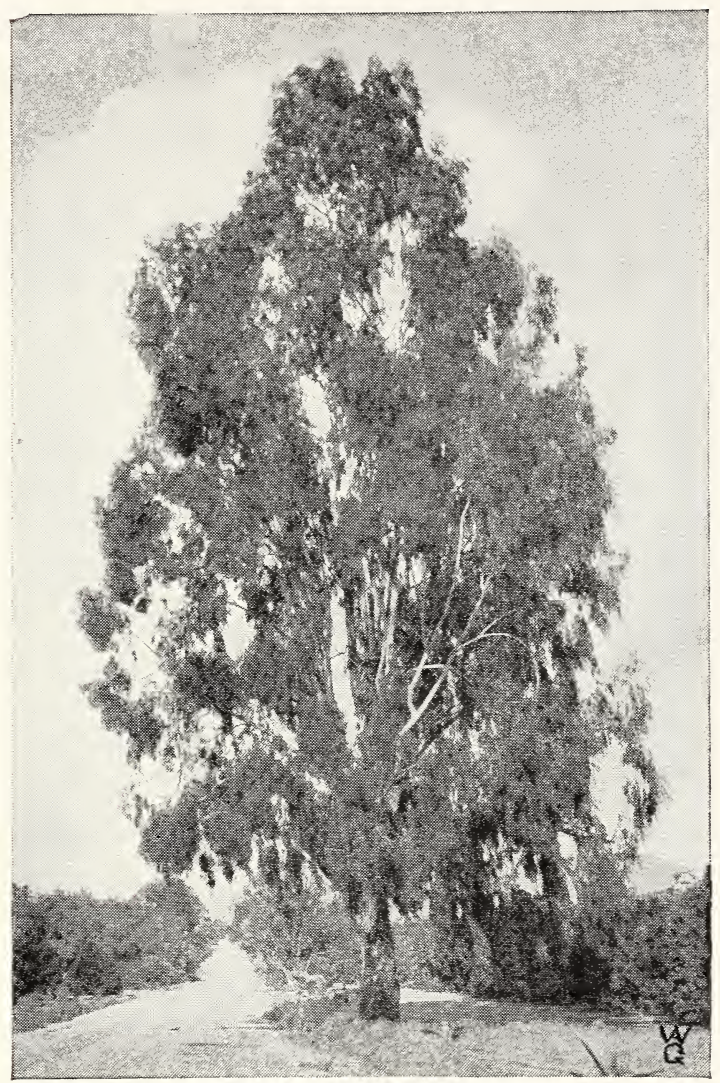

The Picturesque Eucalyptus

ELM (English, American and Cork). Make fire street or avenue trees. Rapid growers. 6 to 8 ft., $\$ 1.50$ each.

EUROPEAN LINDEN (Lime Tree). The fanols street tree of Eurofe. $6 \mathrm{ft} ., \$ 1.50 \mathrm{\epsilon ach}$.

EUCALYPTUS GLOBUL US (Blue Gum). No description needed. $75 \mathrm{c}$ to $\$ 1.25$ each.

EUCALYPTUS ROSTRATA (Red Gum). 75c to $\$ 1.25$ each.

GREVILLA ROBUSTA (Silk Oak). Raץid growirg, fair-sized tree. Sweet scented orange-yellow flowers. Stands drought well. Keep well cut back. $\$ 1.25$ each. 
Evergreen and Deciduous Trees for Park, Street and Home Planting

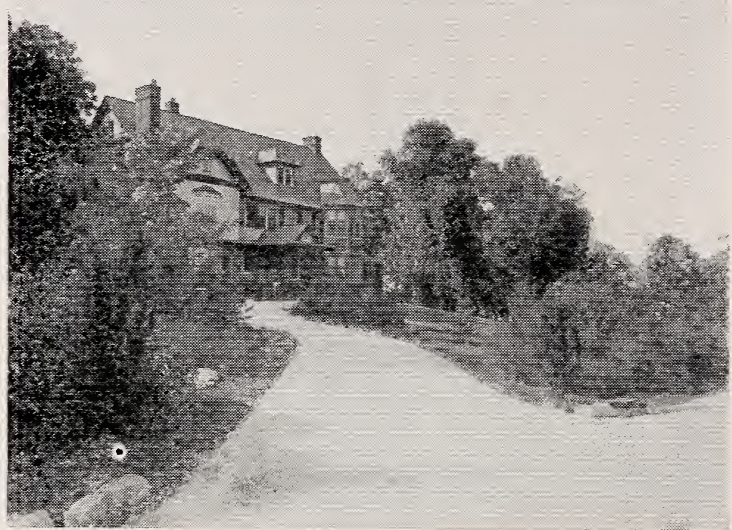

Trees and Shrubs Make the Home and Home Grounds the Pride of the Owners. An Investment That Has a Twofold Value

LAUREL (English). One of the most effective shrubs. Large, shining leaves, can be trimmed into almost any shape. Nakes fine specimen flants. $\$ 1.50$ to $\$ 3.50$ each.

LABURNUM (Golden Chain). A small tree of quick growth. Flowers fragrant and hang in long, yellow racemes, resembling Wistaria. $t \mathrm{ft}$., $\$ 1.25$ each.

LEPTOSPERMUM (Australian Tea Tree). Thrives well in this State. $75 \mathrm{c}$ each.

MAPLE (English, Norway and Silver). Very handsome street or avenue trees. Too well known to need any description. 6 to $8 \mathrm{ft}$., $\$ 1.25$ and $\$ 1.50$ each.

MAGNOLIA (Grandiflora). Slow growing tree. Very hardy and long lived. Large, green leaves. Flowers very large and pure white. In cans, $\$ 3.00$ to $\$ 7.50$ each.

IULBERRY (Tea's Weeping). A most uncommon but very graceful weeping tree; form a perfect umbrella head, with branches hanging to ground. 6 to $8 \mathrm{ft}$., $\$ 3.00$ to $\$ 5.00$ each.

MAIDENHAIR TREE (Gingko Biloba). Native of China. A most remarkable tree, rather slow growing. Leaves shafed like maidenhair fern. 6 to $8 \mathrm{ft} ., \$ 1.25$ to $\$ 1.50$ each. 
Evergreen and Deciduous Trees for Park, Home and Street Planting

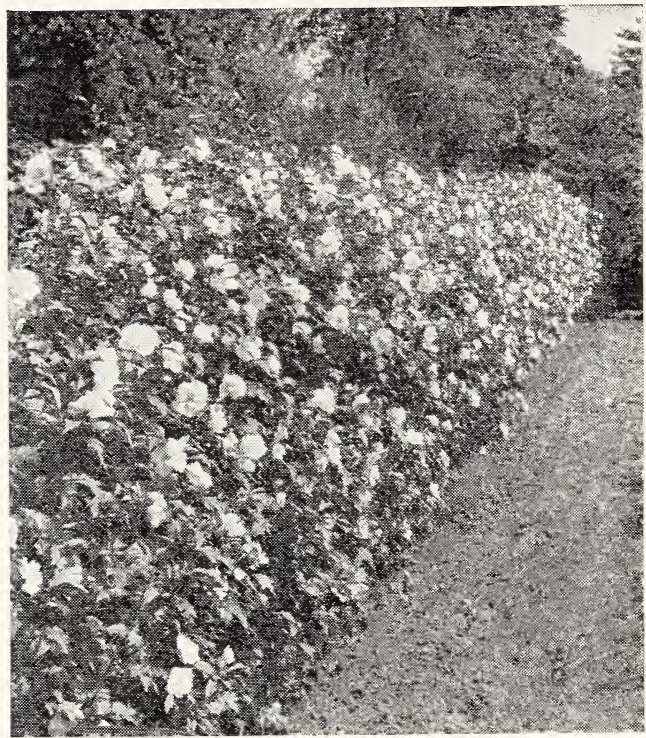

Rose of Sharon (Althea) Used as a Hedge

POPLAR (Lombardy). Grows to a great height. Very distinct. 6 to $8 \mathrm{ft}$., $\$ 1.25$ each.

TULIP TREE. Medium-sized tree. Large, green leaves, flowers resembling a tulip (hence the name). 6 to $8 \mathrm{ft}$., $\$ 1.25$ each.

ROSE OF SHARON (Althea). Covered with bloom during several months in summer. Hardy, tall growing shrubs. Uncommon. \$1.50 each.

ORIENTAL PLANE (European Sycamore). Most highly recommended by all authorities for street planting in California. Fast and vigorous growers. Stand pruning well. Cannot be excelled as shade trees. Free from insect pests and disease. Thoroughly endorsed by us as a good street tree. Largely planted in Sacramento's newer sections and around the postoffice. A fine lot of straight trees. Price from $\$ 1.00$ to $\$ 1.75$ each.

\section{THIS IS A SPECIALTY WITH US}

PEPPER TREE. So well known here, no description necessary. Native of Mexico. 75 c to $\$ 1.25$ each. 
Evergreen and Deciduous Trees for Park, Street and Home Planting

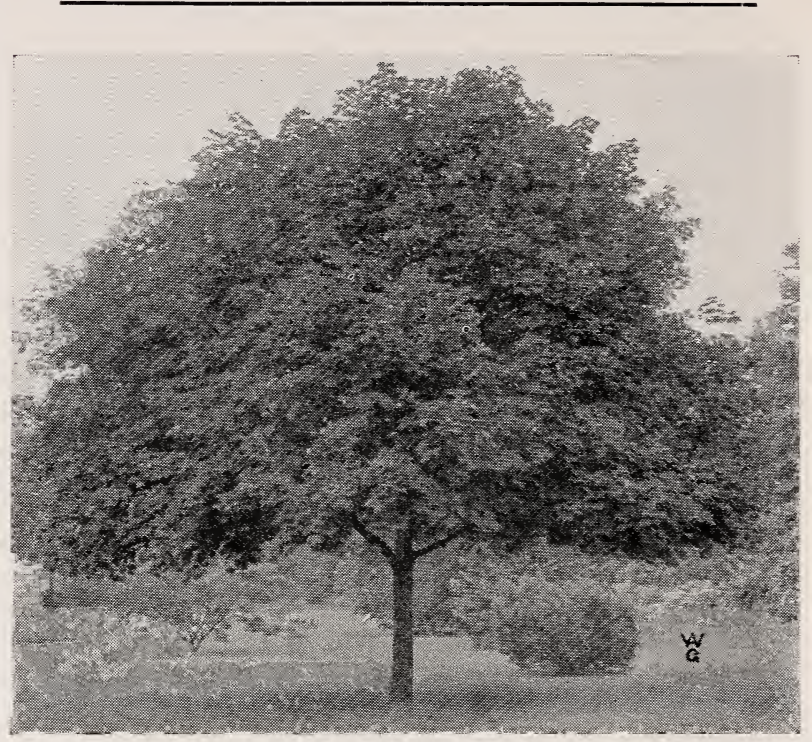

Norway Maple

PAULS SCARLET THORN. Double flowering. Small tree of quick growth. Very fine heads of berries. 4 to $6 \mathrm{ft}$., $\$ 1.50$ each.

SEQUOIA GIGANTEA (California Big Tree). $\$ 2.00$ to $\$ 3.00$ each.

SEQUOIA SEMPERVIRENS (Redwood). $\$ 2.00$ to $\$ 3.00$ each.

AUCUBA JAPONICA. Fine for tubs. \$2.25 each.

BROOM (Spanish and Scotch). Fine plants, 4 to $5 \mathrm{ft}$. high, covered with bright yellow flowers in early spring. $75 \mathrm{c}$ each.

CAMELLIA JAPONICA. Beautiful winter flowering evergreen. Dark green foliage. Unusual waxlike flowers. Red, pink and white. $\$ 5.00$ to $\$ 9.50$ each.

ACACIAS. Beautiful fast-growing evergreen trees, well suited to California, many of them covered with bloom in early spring. Fine shade trees. Mollissima (yellow flowers), Melanoxylon (black), no flowers, Baileyana (lemon-yellow flowers), very early bloomers. $\$ 1.00$ and $\$ 1.50$ each.

WHITE FIR (Concolor). Rapid-growing tree. One of the finest and hardiest of the firs, standing well in the most exposed positions. 4 to 5 feet high, $\$ 5.00$ each. 
Evergreen and Deciduous Trees for Park, Home and Street Planting

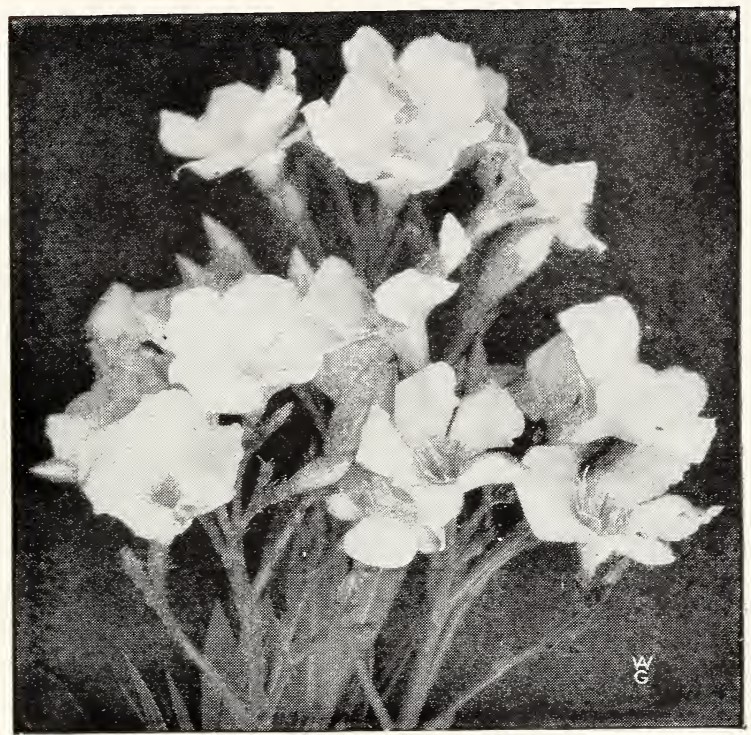

Oleander Blossoms

OLEANDERS. Well adapted to California, though native of Asia. Large green foliage; flowers very fragrant; bloom all summer. Pink and white. $\$ 1.00, \$ 1.25$ and $\$ 1.50$ each.

CRATAEGUS PYRACANTHUS (Burning Bush). A compact evergreen shrub. Small white flowers in spring, followed by masses of bright orangecolored berries. $\$ 1.50$ and $\$ 2.50$ each.

VERONICA. Native of New Zealand. Small shrub. Produces numerous spikes of light blue flowers. Also in dark purple. $\$ 1.25$ and $\$ 1.50$ each.

CHINESE MAGNOLIA. Very rare. Large flowers are in full bloom before foliage appears. $\$ 3.50$ and $\$ 4.00$ each.

MAHONIA AQUAFOLIUM (Oregon Grape). A native of the Pacific Coast. Purplish, prickly leaves, with bright yellow flowers; blue-black berries; fine, strong, bushy plants. $\$ 1.00$ to $\$ 2.50$ each.

ENGLISH HOLLY. Very uncommon in California. Foliage very lustrous. Covered with red berries in fall and winter. 3 to $3 \frac{1}{2} \mathrm{ft} ., \$ 5.00$ each. 


\section{Evergreen and Deciduous Trees for Park, Home and Street Planting}

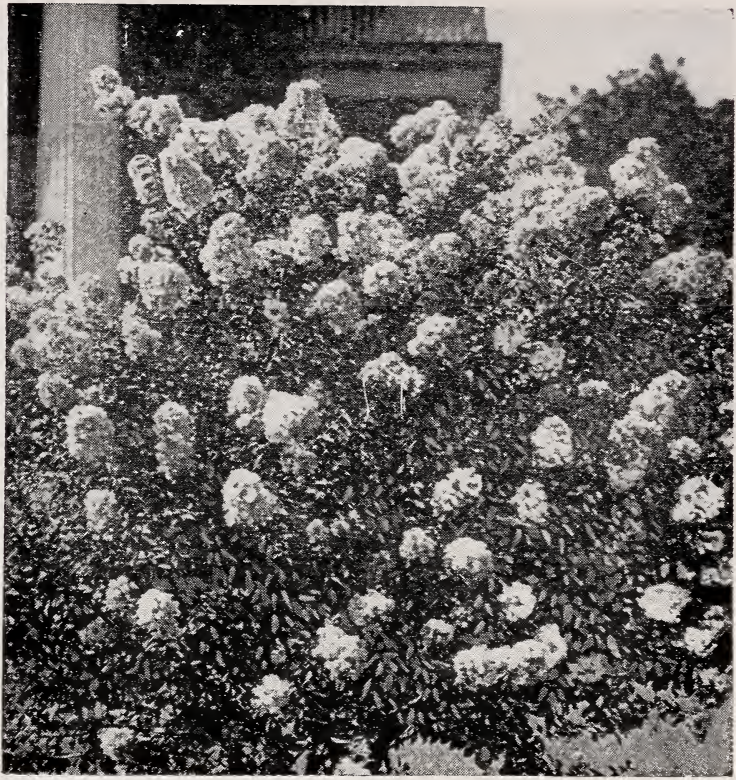

Crape Myrtle

BUDDLEIA (Butterfly Brush.) Blooms continuously throughout the summer, flowers resembling lilacs in color and form. Does well planted in masses. $\$ 1.00$ to $\$ 1.50$ each.

CRAPE MYRTLE. Strong growing shrub; well adapted to almost all conditions of soil. Leaves bright green. Beautiful crimped petals, blooming all summer. $\$ 1.50$ each.

NORWAY MAPLE. A large and very handsome tree. Well adapted to superior California conditions. $\$ 1.25$ and $\$ 1.50$ each.

SILVER MAPLE. Rapid growing tree, foliage bright green on top, silvery sheen below. Does well here. $\$ 1.25$ and $\$ 1.50$ each.

FERNS AND PALMS. A large stock of all the leading varieties of ferns and palms always on hand at attractive prices. 
Vines to beautify the home. Some choice varieties of unusual merit

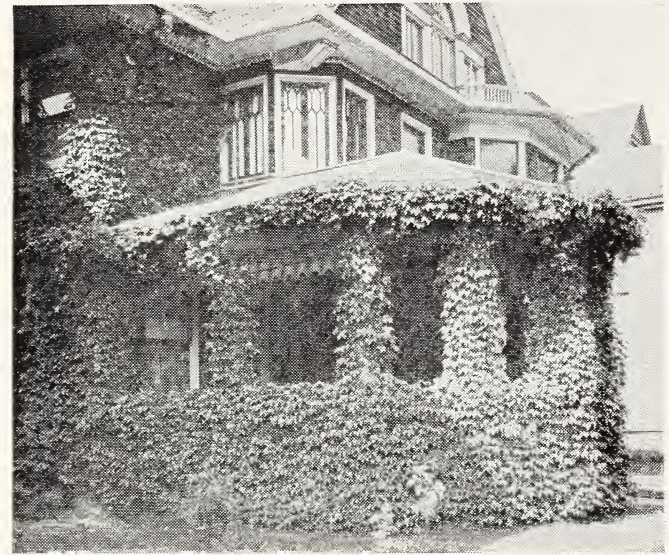

Boston Ivy

\section{VINES}

WISTARIA. One of the best hardy climbers, producing great clusters of flowers. The Wistaria is the queen of the climbing vines.

SINENSIS. The favorite variety; violet blue, perfumed.

ALBA. Similar to Sinensis, but white. $75 \mathrm{c}$ to $\$ 3.50$ each.

AMPELOPSIS VEITCHI (Boston Ivy). The most popular climbing plant for covering walls. Clings to the smoothest surface like ivy. Rich olive green in summer, changing to scarlet in fall. Cut plants back to six inches when planting. $75 \mathrm{c}$ each.

VIRGINIA CREEPER. Rapid grower; its deep-green foliage assumes brilliant shades of yellow, crimson and scarlet in the fall. $75 \mathrm{c}$ each.

CLEMATIS (Montana). The best of the early spring flowering climbers. Perfectly hardy and a rapid grower. Covered with masses of white flowers. Clings to any support. $50 \mathrm{c}$ and $75 \mathrm{c}$ each.

CLEMATIS (Jackmanii). Rich purple, very popular. $75 \mathrm{c}$ each. 
Vines and Hedge Plants. A few of the best varieties; all healthy, vigorous plants

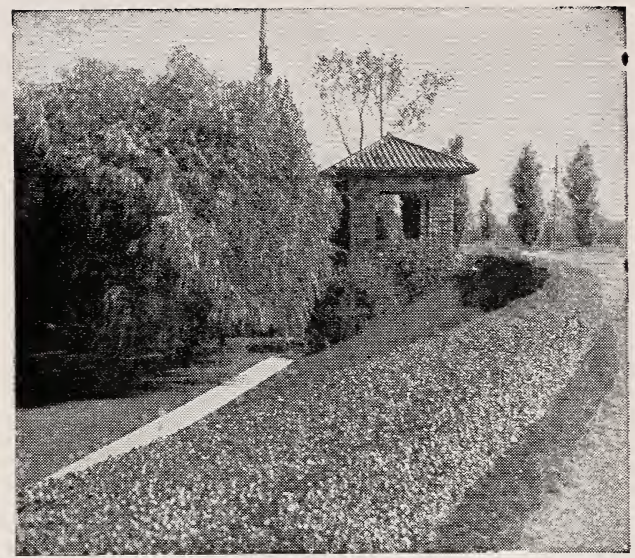

Have you a place for a Hedge? This is Galifornia Privet

CLEMATIS (Paniculata). Pure white, fragrant flowers. Blooms August and September. 50c and $75 \mathrm{c}$ each.

HONEYSUCKLE (Halleana). Flowers pure white, turning to yellow. Fragrant. 75c each.

HONEYSUCKLE (Red Tartarian). Brilliant coral red clusters of flowers. \$1.00 each.

Many other varieties that space does not permit to list.

\section{HEDGE PLANTS}

CALIFORNIA PRIVET (Ligustrum). Of all the hedge plants, this is the most popular, and more of it is planted than all others combined. It is of free growth and succeeds almost anywhere. Cut back severely before planting. Plant twelve inches apart. Strong, bushy plants, two and three years old, at $\$ 8.00$ and $\$ 10.00$ per 100 , depending on height and age.

BERBERIS THUNBERGI. Nothing equals this beautiful deciduous hedge, where a dwarf hedge is wanted. Leaves small, rich green, turning to rich brilliant colors in fall. Scarlet berries. Perfectly hardy. Plant 15 to 18 inches apart. $75 \mathrm{c}$ to $\$ 1.50$ each.

LAURUSTINUS. Makes a very beautiful hedge or screen. Covered with white blossoms or buds almost continuously. $50 \mathrm{c}$ to $\$ 1.50$ each. 
Bedding, Ornamental Plants to brighten the garden, furnish flowers in the home

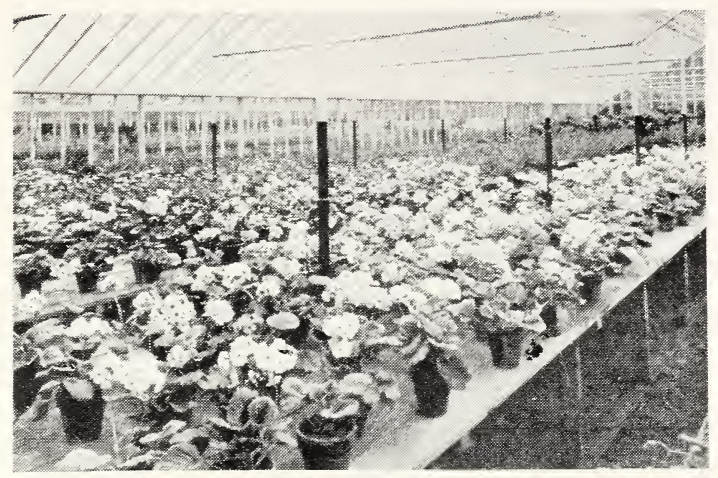

Interior of Flowering Plant House

SPIRAEA Van Houttei (Bridal Wreath). Nakes a beautiful, informal flowering hedge. In late spring it is literally covered with a profusion of white bloom. $\$ 1.00$ to $\$ 1.50$ each.

DWARF BOXWOOD. Makes a beautiful, low, evergreen border plant. $10 \mathrm{c}, 15 \mathrm{c}$ and $20 \mathrm{c}$ each. Larger, 35c and 50c each.

BOX BARBERRY. An exquisite, new, perfectly hardy edging for formal beds. Beautiful emeraldgreen in the spring, changing to a pleasing soft green in the summer and a rich red in the fall. Plant 4 inches apart for a low border, and keep pruned to whatever height you want. Plants 1-year-old, $\$ 10.00$ per 100 .

\section{Bedding and Ornamental Plants}

ASTER. In variety. 35c per dozen.

BEGONIAS. Splendid collection. 50c to $\$ 1.00$ each.

CALLA LILY. 10c each, $\$ 1.00$ per dozen.

CANNAS. From $15 \mathrm{c}$ to $25 \mathrm{c}$ each.

CARNATIONS. Leading varieties. Ready March 1st. $15 \mathrm{c}$ each, $\$ 1.50$ per dozen.

COREOPSIS (Lanceolata). Yellow. 50c per dozen.

CHRYSANTHEMUM. Best varieties. \$1.C0 per dozen.

COLEUS. Variety. 25c to $\$ 1.00$ each.

CYCLAMEN. $\$ 1.00$ to $\$ 3.00$ each. 
Bedding, Ornamental Plants to brighten the garden, furnish flowers in the home

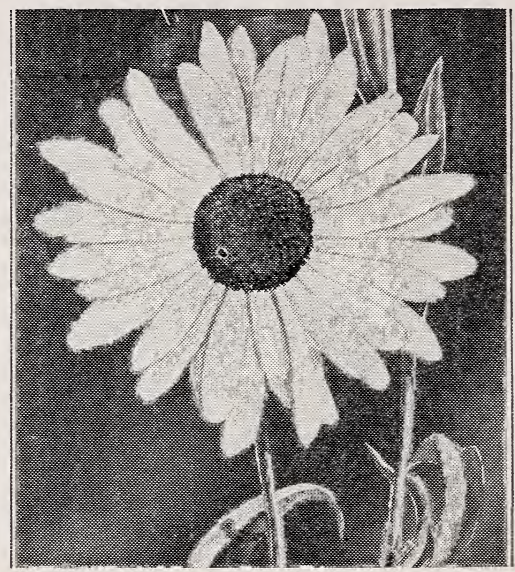

Shasta Daisy

CALADIUM ESCULENTUM (Elephant's Ear). 25c each.

DAISIES, SHASTA. Strong flants. 35c per dozen. FUCHSIAS. Best varieties. $25 \mathrm{c}$ to $75 \mathrm{c}$ each.

GERANIUMS. Single and Double. Red, White and Pink. $\$ 1.50$ per dozen.

GERANIUMS. Ivy-Leafed, running and climbing. $15 \mathrm{c}$ each, $\$ 1.50$ per dozen.

HELIOTROPE. $25 \mathrm{c}$ to $50 \mathrm{c}$ each.

LOBELIA. Dwarf, compact, for borders. 35c per dozen.

MARGUERITE (Mrs. Saunders). 15c to $75 \mathrm{c}$ each.

MESEMBRYANTHEMUM (Rosea). $\$ 1.00$ per dozen.

PANSIES (Steele's Giant). 50c per dozen, $\$ 3.50$ per 100.

PETUNIAS. Single or double. 25c each.

PHLOX (English). Hybrids. 35c clump.

SALVIAS. SPLENDENS (Scarlet Sage). $\$ 1.00$ per dozen.

SANTOLINA. Silver grey edging plant. 5cc per dozen.

STOCKS (Gilliflower). Red, pink, white. 50c per dozen.

VERBENAS. Varieties. 50c per dozen.

ZINNIA (Grandiflora). 50c per dozen. 
FRUIT TREES. Although we carry most of the varieties of fruit trees, and can fill orders for almost any of them, we do not list them this season. Prices run about $70 \mathrm{c}$ each, except Cherries, which are $\$ 1.00$ each.

ENGLISH WALNUTS. Grafted Franquette, Mayette and Eureka. 4 to $6 \mathrm{ft}$., $\$ 1.75$ and $\$ 2.00$ each.

CHESTNUT (European). 4 to $6 \mathrm{ft}$., $\$ 1.25$ each.

OLIVES (Mission). \$1.25 each.

ORANGES. Washington Navel and Valencia. $\$ 2.50$ each.

LEMONS (Eureka). \$2.50 each.

POMELO (Grape Fruit). \$2.50 each.

CURRANTS. Perfection, Black Naples, Fay's Prolific, Red Dutch. 25c each, $\$ 2.00$ for 10.

GOOSEBERRIES. Oregon Champion. 25c each, $\$ 2.00$ for 10 .

BLACKBERRIES. Mammoth, Loganberry, Pheromenal, Thornless. 25c each, $\$ 2.00$ for 10 .

RASPBERRIES. Superlative, California Surprise. $15 \mathrm{c}$ each, $\$ 1.00$ for 10 .

STRA WBERRIES. Klondike, Branciywine. 30c for 10, \$2.00 per 100.

RHUBARB. Wagner's Giant Subdivisions. (Guaranteed genuine subdivisions, direct from Wagner's.) 25c each, \$2.00 for $\$ 10, \$ 15.00$ per 100 .

\section{BUSH ROSES}

TWC-YEAR-OLD. PRIGE 50 CENTS EACH, \$4.50 PER TEN, UNLESS OTHERWISE NOTED.

AMERICAN BEAUTY. Deep rose to carmine-cerise. BESSIE BROWN. Creamy white. Large and fragrant.

CECIL BRUNNER. Salmon pink. Great favorite.

CAROLINE TESTOUT. Beautiful pink. Free bloomer. Highly recommended.

FRAU KARL DRUSCHKI (White American Beauty). Snowy white, large flowers, very beautiful tapering buds. Strong grower. The very best white. Superb.

GENERAL McARTHUR. Fiery red. Magnificent color. Very free bloomer and has the richest fragrance. Highly recommended.

HADLEY. Brilliant deep velvety crimson. Veryscarce. $75 \mathrm{c}$ each. 


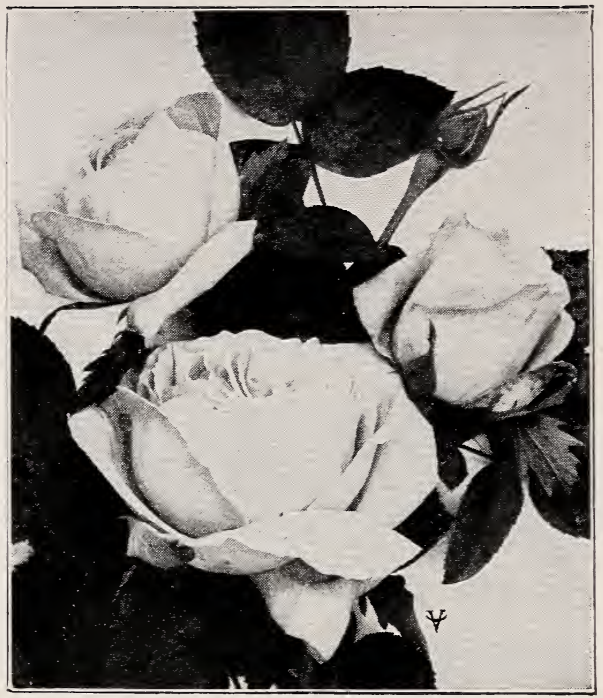

K. A. Victoria Rose

HOOSIER BEAUTY. Glowing crimson, beautiful in both bud and flower. Buds lorg and slender. Flowers large and full. $75 \mathrm{c}$ each.

IRISH ELEGANCE (Single). Apricot, shaded orange and pink. Extremely handsome in bud. Always in bloom. A great favorite.

IRISH FIRE FLAME (Single). One of the most pleasing color combinations found in any variety. The long pointed buds are deep maddery orange, splashed with crimson. Opens up to a large single flower of rich, satiny old-gold. Worthy of a prominent place in every garden. $75 \mathrm{c}$ each.

J. B. CLARK. Intense deep scarlet, heavily shaded blackish crimson. Very fine.

KILLARNEY. Flesh-colored pink. Buds long and beautiful, free bloomer. Very fragrant.

KILLARNEY BRILLIANT. Most brilliant pink color. Strong grower and blooms very freely. Delicious perfume.

KAISERIN AUGUSTA VICTORIA. White. Blooms are very large, full and globular, and produces until late autumn.

LADY ALICE STANLEY. Deep coral-rose on outside of petals. Pale flesh on inside. Continuous bloomer, very fragrant. 
All Roses offered are two-year-old, and will bloom this year

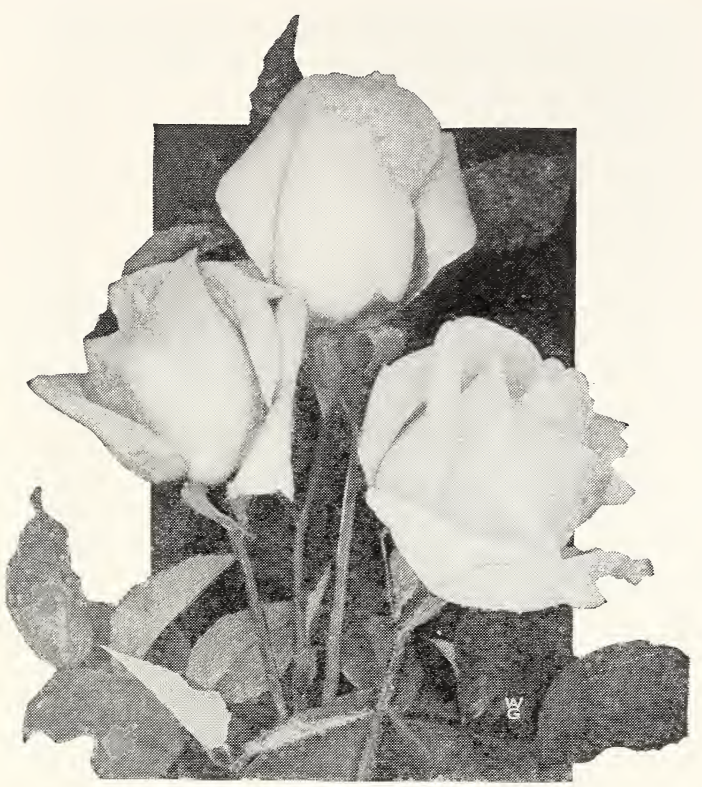

Pink Maman Gochet

LOS ANGELES. One of the finest Roses ever introduced. Flame pink, toned with coral, and shaded translucent gold at the base of petals. Very fragrant. Buds long and pointed. Nothing finer. $\$ 1.50$ each.

LADY HILLINGDON. Pleasing shade of orangeyellow. Very fine in the bud stage. Free bloomer.

LILLIAN MOORE. New. This is the $\$ 10,000$ Prize Rose. Deep pure Indian-yellow. Free bloomer. $75 \mathrm{c}$ each.

LYON. Shrimp pink color, center shaded to chrome yellow. Gorgeous color, very fragrant, good shape, very popular. $75 \mathrm{c}$ each.

LA FRANCE. Silvery pink, one of the best of the pinks; constant bloomer and very sweet scented.

MME. EDOUARD HERRIO'T'T (Daily Mail Rose). The buds, which are long and pointed, are coralred, shaded yellow at base. A vigorous grower. $75 \mathrm{c}$ each.

MADAM COCHET (White). Clear white, buds long and pointed and very solid.

MADAM COCHE'T (Pink). One of the finest pinks. Deep rose pink. 
$\overline{\text { All Roses offered are two-year-old, and }}$ will bloom this year

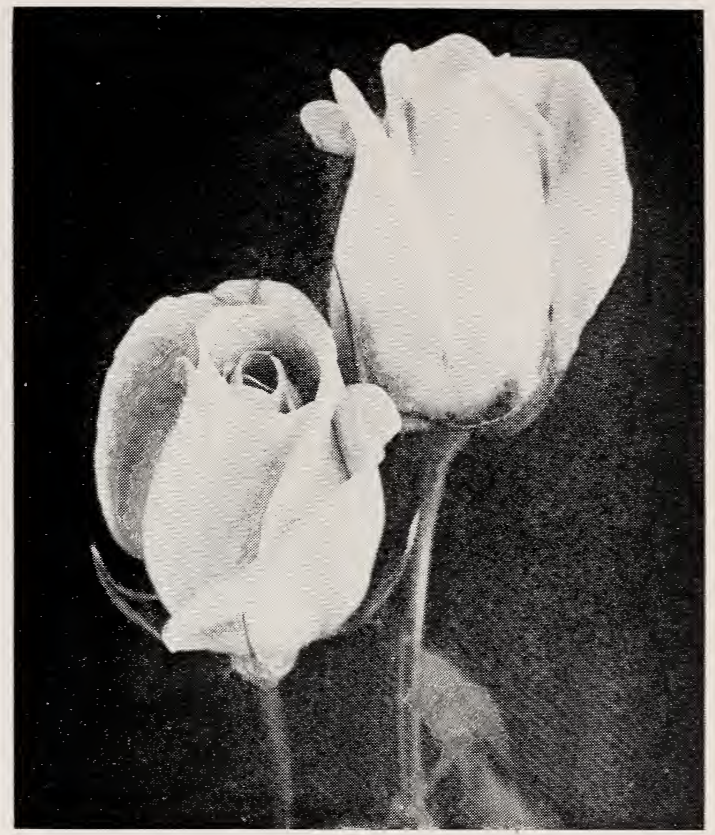

My Maryland

MRS. AARON WARD. Distinct shade of apricotyellow. Free bloomer. Flowers full and very well formed.

MRS. JOHN LAING. Soft pink, free flowering. Exceedingly fragrant. A beautiful rose.

MRS. W. CHRISTY MILLER. Blooms of enormous size. Rosy carmine.

MY MARYLAND. Bright salmon pink. Strong grower. Very fragrant and free bloomer.

OPHELIA. Light salmon, flesh pink, shading to yellow. Many rosarians consicer this the best rose of its color. Blooms freely all season.

PAUL NEYRON. The largest of all roses. Very clear salmon-pink. Bright and couble. Highly perfumed.

PAPA GONTIER. A magnificent rose. Brilliant carmine, very fragrant. A great favorite.

PRINCE CAMILLE DE ROHAN. Deep velvety crimson. One of the best dark-red roses. 
$\overline{\text { All Roses offered are two-year-old, and }}$ will bloom this year

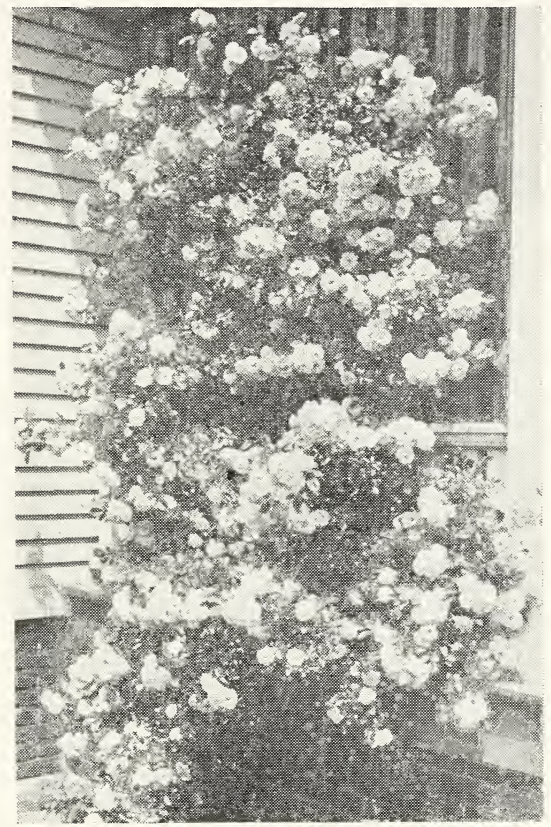

Philadelphia Rambler

PHILADELPHIA RAMBLER. Light crimson. An improvement on Crimson Rambler. Large, double flowers.

RADHANCE. Soft carmine pink. Very sweet fragrance. Vigorous grower, free bloomer.

RADIANCE (Red). Large, double bloom, clear red. Holds color well.

ULRICH BRUNNER. Bright, cherry red. Very fine. Long stems and beautiful flowers. Highly recommended.

SUNBURST. A magnificent yellow, shaded orangecopper. Long buds on strong stems. One of the best. $75 \mathrm{c}$ each.

\section{CLIMBING ROSES}

TWO-YEAR-OLD. PRIGE 50 GEN'TS EACH, \$4.50 PER TEN, UNLESS OTHERWISE NOTED.

CLIMBING BANKSIA (White). A thornless, climbing rose, glossy foliage, flowers small, but bloom in great profusion in early summer.

CLIMBING BANKSIA (Yellow). Same as white. Deep yellow: 


\section{$\overline{\overline{A l l} \text { Roses offered are two-year-old, and }}$ will bloom this year}

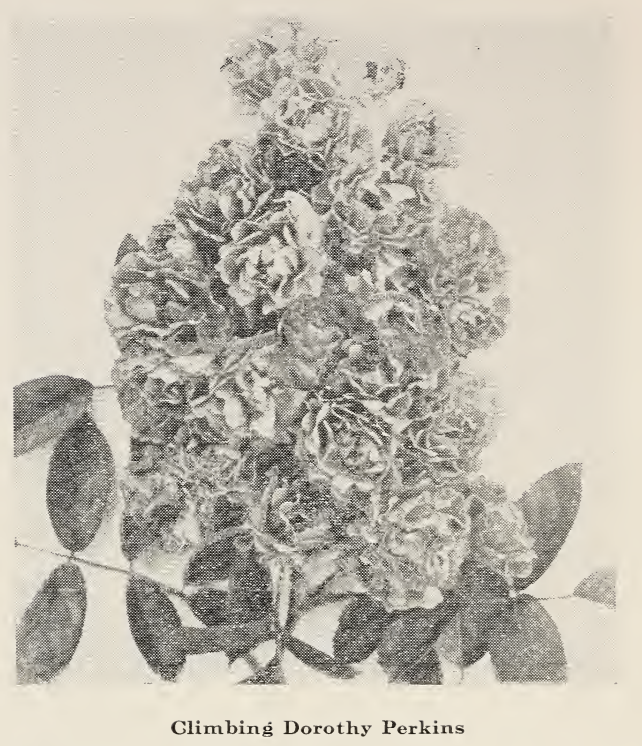

CLIMBING CHEROKEE (Pink). Clear pink.

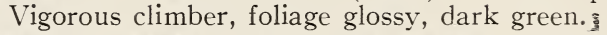

CLIMBING MME. CECIL BRUNNER. Beautiful salmon pink. The well-known "Baby Rose." Same as bush.

CLIMBING CAROLINE TESTOUT. Large, beautiful pink flowers. Blooms all season.

CLIMBING COCHET (White). Very strong climber, creamy white, long pointed solid bud.

CLIMBING DOROTHY PERKINS. Shell pink. Blooms in springtime only. Sweet fragrance.

CLIMBING KAISERIN AUGUSTA VICTORIA. Very popular white.

CLIMBING LA MARQUE. A magnificent white climber. Continuous bloomer.

CLIMBING MARECHAL NIEL. A beautiful yellow. Buds are well shaped and solid. Delightful fragrance. One of the very best.

CLIMBING PAPA GONTIER. Dark, rosy crimson, fine, large, sweet scented buds. Continuous bloomer.

CLIMBING REINE MARIE HENRIETTE. Cherry red. Flowers large and fragrant. A fine climber. Liable to mildew in the early season.

And many others that room does not permit us to list. 


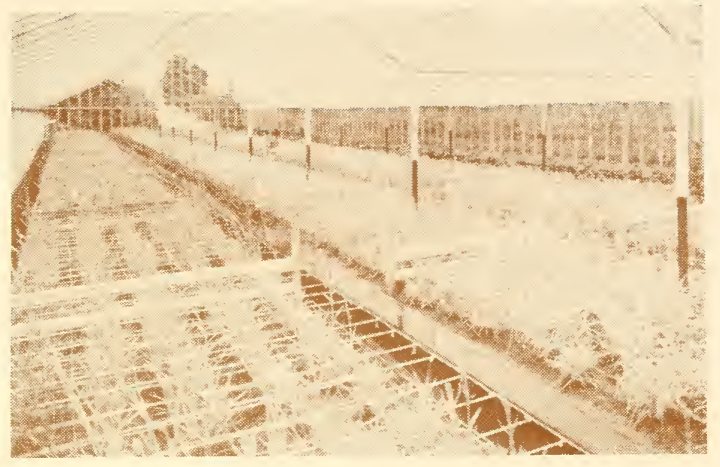

Interior of Carnation Ilouse
$(100 \times 35$ Feet $)$

\section{FINAL WORD:}

Trees are still scarce, so we advise ordering early. Even if not ready to plant now, you should book your requirements, so as to insure delivery when you are ready.

GUARANTEE. We accept and fill your order with the understanding that the stock must satisfy vou. That's plain, and means just what it says. You are to be the sole judge. Your money back cheerfully if you are not satisfied.

SAFE DELIVERI. Te guarantee safe arrival. Shipment lost or damaged in transit will be replaced without charge. Claims should be made within five days from date of Invoice.

\section{TERMIS:}

Cash with order. Free delivery to depot or steamer here. Packing at actual cost.

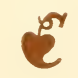

\section{East Lawn Nursery}


General Nursery

A N D

Bedding Stock

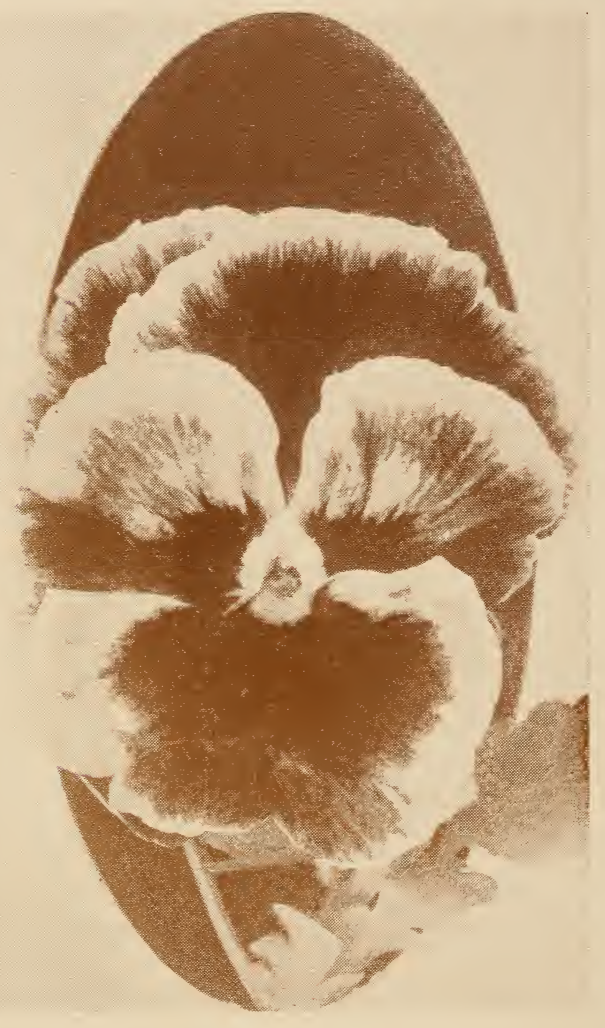

Steele's Giant Pansy Plants. \$3.50 per 100

\section{East Lawn Nursery}

SACRAMENTO, CALIFORNIA 